\title{
Technology Based Hinduism Learning And Multiple Intelligences
}

\author{
I Ketut Sudarsana ${ }^{1}$, Ni Kadek Surpi ${ }^{2}$, I Gusti Made Widya Sena ${ }^{3}$, I Gusti Ngurah Dodi \\ Setiawan $^{4}$ \\ \{liketutsudarsana@uhnsugriwa.ac.id\} \\ ${ }^{1234}$ Universitas Hindu Negeri I Gusti Bagus Sugriwa Denpasar, Bali, Indonesia
}

\begin{abstract}
The study of Hinduism in Indonesia has not been effective enough. In today's digital era, the use of reversing classroom methods combined with technology can be a solution for the better learning activity that can embrace the student's diversity intelligence. The theory of multiple intelligences is relevant within learning principle. Howard Gardner states of eight human intelligence theories that are linguistic intelligence, logical-mathematical intelligence, spatial intelligence, kinesthetic intelligence, musical intelligence, interpersonal intelligence, intrapersonal intelligence and naturalist intelligence. This theory will combine with technological developments for would be a model of Hinduism religion learning in order more effective and fun.
\end{abstract}

Keywords: Technology; Hinduism Learning; Multiple Intelligences

\section{Introduction}

Learning and education is the component that cannot be separated. The success of education will happen based on the effectiveness of learning. This is because the learning process is the main spearhead of educational activities that will help the realization of educational goals. The development of the quality learning process in educational institutions needs to be the top priority. One of the learning process is Hinduism religion teaching. Learning Hinduism in Indonesia has not been effective enough. Students have learned Hinduism from elementary school to college. Unfortunately, in reality there are many students who have not been able to carry out religious teachings properly in their everyday life. Even Hinduism today has become a boring lesson for students and considers it as an abstract and difficult subject to understand. The condition is certainly caused by many factors. One of them is the lack of Hindu learning models of effective development [1]. In addition, the learning of Hinduism will be effective if it relevant to the diversity of students potential and be able to make student interest in learning. In its application, the learning of Hinduism will be effective when paying attention to technological developments and individual differences of students, such as differences in potential and intelligence. Each student has their own uniqueness that is different with each other. The lack of teacher's attention to the development of technology and the diversity of student intelligence was detected as one of the lack factor of Hinduism learning process successful.

The corelation of Learning process that can embrace the diversity of student intelligence with multiple intelligences is relevant to the principle of learning. This theory was pioneered 
by Howard Gardner which gave a new paradigm of education and learning, especially related to the concept of intelligence. In general, the goals of education and learning are more directed towards the development of intellectual intelligence (IQ). IQ is the only measure of intelligence so that the diversity of individuals in the aspect of intelligence gets less attention. Even though the facts on the ground show that people who are successful in life are not always dependent on the level of intellectual intelligence. The success of human life occurs a lot in various fields of work. Some have succeeded in the arts, sports, social, and so on. The theory of multiple intelligences shows that any individual who is taught in ways that involve his own dominant intelligence will be able to learn, understand, and apply knowledge more effectively. In line with the opinion above, Hoerr mentions KM (Compound Intelligence) has the potential to help children learn and can create an environment that allows adults to learn as well [1].

Based on the theory stated by Howard Gardner, the eight human intelligences are linguistic intelligence, mathematical-logical intelligence, spatial intelligence, kinesthetic intelligence, musical intelligence, interpersonal intelligence, intrapersonal intelligence, and naturalist intelligence. This paper tries to explain the learning of Hindu religion based on the technology development and the principles of multiple intelligences. Based on the use of multiple intelligence technologies and principles, it is hoped that learning of Hinduism will be more effective and enjoyable.

\section{Method}

This type of research is descriptive analysis. This design does not make too far conclusions on existing data because the purpose of this design is only to collect facts and describe them thoroughly and thoroughly in accordance with the problem to be solved. The data collection method in this research was carried out with a literature study that is collecting data from literature books and other readings that support this research.

\section{Result and Discussion}

\subsection{Technology And "Reversing Class Room"}

The development of science and technology has a major impact on the education system in the world. Technology helps teachers to teach and students learn, but this is still poorly utilized by some teachers. Believe or not, the teacher must follow the development of educational technology to bring students ready to live in the future, not even in the past. This situation must be immediately realized by all parties and equally grow up for an education system that is in line with the development of science and technology. One solution that can be applied to maximize learning is to utilize technology and "reverse the classroom".

The method of reversing the classroom is the learning process done in the classroom conducted at home and home-study activities conducted in the classroom. Simply put, the teacher's lecture is done at home and the home work usually done at home will be done in class. This method is commonly use in education nowadays. In today's digital era, classroomaltering methods combined with technology can be a solution for the better learning activity. According to Khan, the reversed classroom is a simple way, but to make the classroom more appealing to everyone involved. Reversing the classroom is done because each student has 
different speeds in processing information [2]. Silberman says we can give something to students quickly, but students will forget what we did more quickly [3]. This opinion provides an understanding that the students just catch little information after listening the teacher's explanation after more than an hour class. This condition is not good for student learning and developing process. Then, the hope of giving material understanding will not work.

To support the method of reversing classroom, one way of learning method that has garnered worldwide attention in recent years is the use of online learning videos. The site of online learning video providers is widely available in cyberspace, one of the popular ones is Khan Academy. Khan Academy contains many videos of subject matter in various languages including Indonesian and can be studied entirely for free with internet access on PC or Smartphone. The utilization of Khan academy can increase parental participation in monitoring children's learning while helping the teacher to know the extent of students' understanding through the various features contained in the application. This good synergy between parents and teachers will be difficult to achieve in conventional methods. By utilizing the video learning of Khan Academy, it will help slow learner students in overcoming learning difficulties by repeating the learning video to understand the material well.

For the Hinduism study, the required material certainly does not yet exist in various online learning sites today. However, the concept of learning Khan Academy can be an inspiration for teachers to make their own learning videos which will later be used in Hinduism learning. Khan Academy's learning video is a simple video that only shows writing and sound that lasts about 10 minutes only. This video making process is easy even for teachers who are not too familiar with technological developments. Although the features in online learning sites become unusable, learning videos made by teachers will still provide a different atmosphere for student learning. The reversing classrooms method combined with learning videos will make it easier for students to learn material and provide more space for teachers in the classroom to develop models of Hinduism learning with the multiple intelligences principles.

\subsection{Multiple Intelligences Learning}

Learning is a system. According to Warsita, learning is an effort to make learners learn or an activity to teach students [4]. The point of view of multiple intelligence as expressed in the concept of multiple intelligences have an impact on the learning process, including the learning of Hinduism. According to Gardner, it is very important that we need to recognize and develop all the various human intelligences and all combinations of intelligence [1]. We are all so different especially because we all have different combinations of intelligence. In addition, according to Gardner it is wrong to assume that IQ is an entity or a single and fixed amount, which can be measured by tests using pencil and paper [5].

Learning in multiple intelligence theory is to develop student intelligence fully. So that it is in line with the goals of national education formulation of the 2003 National Education System Law. Based on that, learning of Hinduism needs to be improved not only for the attainment of cognitive knowledge of Hindu teachings but also orientate to the other development dimensions of students intelligence. On the basis of those thoughts, then in determining the learning objectives of the teacher should try to consider with the intelligence possessed by students in determining learning goals. If so, the aim of learning Hinduism will not be limited to linguistic intelligence only.

If it analyze through the role of the teacher based on the concept of multiple intelligence, then teacher is not the only the center of knowledge in the classroom. Teachers only provide reinforcement and motivation and stand the focus learning to students (student centered learning). The teacher's role is to develop student's creativity so that multiple intelligences 
possessed can grow and develop according to expectations. However, during the process of teaching learning activity, the teacher must be creative in choosing appropriate learning method that is suitable with the context. The implementation of the sequence steps above during the implementation of Hinduism learning is that the teacher must become a model for the students. The main point is that Hindu teachers should be able to act as role models, facilitators and motivators so that teacher can guides students to learn independently.

Base on multiple intelligence concepts, the students are always seen as individual who has diverse intelligence. Each student is having different intelligence advantages. A student can be more prominent in kinesthetic intelligence, but weak in mathematical logic intelligence while the other students are more prominent in musical intelligence but less prominent in naturalist intelligence. The impact of the different intelligences that students have is that the teacher should have the right steps in educating students and respecting students as the unique individuals with the advantages and disadvantages of each student have.

Learning material also has a very important role in the entire curriculum. In the concept of multiple intelligences, good material is material that can suit the variety of different types of student intelligence. Based on that statement, the subject matter present in the process of learning Hinduism must have material related to the diverse intelligences of students.

\section{Conclusion}

Learning Hinduism will be effective when we try to pay attention to technological developments and diversity individual in students, such as differences in potential and intelligence. Each student has a uniqueness that is not the same from one to another. The theory about intelligence stated by Howard Gardner about eight human intelligences, namely linguistic intelligence, mathematical-logical intelligence, spatial intelligence, kinesthetic intelligence, musical intelligence, interpersonal intelligence, intrapersonal intelligence, and naturalist intelligence. Those intelligences will produce the great Hinduism learning model if it is integrate with technology development.

\section{References}

[1] T. Armstrong, Kecerdasan Multiple di Dalam Kelas Edisi Ketiga. Jakarta: Indeks, 2013.

[2] S. Khan, The One World Schoolhouse: Pendidikan Kelas Dunia untuk Siapa pun dan di Mana pun. Jakarta: Noura Books, 2013.

[3] M. Silberman, Active Learning: 101 Cara Belajar Siswa. Bandung: Nuansa Cendekia, 2016.

[4] Rusman, Belajar dan Pembelajaran: Berorientasi Standar Proses Pendidikan. Jakarta: Kencana, 2017.

[5] A. Chatib, M. dan Said, Sekolah Anak-anak Juara: Berbasis Kecerdasan Jamak dan Pendidikan Berkeadilan. Bandung: Kaifa, 2014. 